\title{
EFEKTIVITAS PENGGUNAAN MEDIA PERIKLANAN \\ PADA UNIVERSITAS DEHASEN BENGKULU \\ (Studi Komparatif Iklan Media Lini Atas dan Iklan Media Lini Bawah)
}

Oleh:

\section{VETHY OCTAVIANI \\ Dosen Prodi Ilmu Komunikasi Fakultas Ilmu-Ilmu Sosial Unived Bengkulu}

\begin{abstract}
This study aimed to determine the differences between the effectiveness of advertising media on above the line media and below the line media used by Dehasen University Bengkulu as a promotion strategy. Thisis a quantitative survey research. Data was analyzed byusing a different test of Paired Samples T-Test. The effectiveness of advertisements was analyzed by using a descriptive analysis dimension of EPIC (Emphaty, Persuasion, Impact, dan Communication) Model. The result showed that there are differences in the form of advertising effectiveness of UNIVED Bengkulu presented on above the line media and below the line media in influencing target audience. Emphatically, the advertisement on the top line media was able to utilize the advantages, such as visual excess in newspaper, audio visual in television, and strategic value of banners or billboards. So, persuasively, it's able to strengthen the characters of the brand as well as foster the perception that UNIVED was identical to personal needs of being able to build awareness, understanding, and action. Meanwhile, advertisement on the bottom line media also proves its effectiveness mainly on media brochures or leaflets which have visual excess and wide space to convey the message. Another media, poster, had the same visual strength as well. However, it cannot assist optimally in associating the advertisement because it did not support the laying image that can affect audience comprehension.
\end{abstract}

Key words: effectiveness, advertisement, above the line media, below the line media, EPIC Model

\section{PENDAHULUAN}

Jumlah mahasiswa merupakan salah satu persoalan penting yang membutuhkan perhatian khusus dari lembaga perguruan tinggi swasta. Bahkan ada perguruan tinggi swasta yang gulung tikar dikarenakan tidak mampu memenuhi kuota mahasiswa yang harus dikelola. Jumlah mahasiswa yang dimiliki oleh suatu perguruan tinggi secara proporsional akan memberikan kontribusi dalam kelangsungan dan penyelenggaraan proses pendidikan, sehingga dapat mendukung peningkatan kualitas civitas akademik baik mahasiswa, tenaga pengajar, tenaga administrasi, dan dalam jangka panjang dapat memantapkan posisi strategis perguruan tinggi itu sendiri. Oleh karena itu, perguruan tinggi harus gencar melakukan kegiatan promosi agar dapat memperoleh mahasiswa sebanyakbanyaknya.

Kegiatan periklanan dalam perguruan tinggi erat kaitannya dengan dimensi perguruan tinggi yang ke empat yaitu dimensi koorporasi. Sebagai lembaga koorporasi, perguruan tinggi memberikan jasa kepada masyarakat berupa pendidikan tinggi dalam bentuk proses belajar mengajar, penelitian dan 
pengabdian kepada masyarakat. Sebagai lembaga koorporasi, perguruan tinggi juga menghadapi persaingan antar perguruan tinggi lain sehingga dianggap perlu untuk memperkenalkan produknya pada masyarakat agar dikenal dan dipilih. Pengenalan perguruan tinggi salah satunya dengan menggunakan iklan (Indrajit dan Djokopranoto, 2006:35).

Iklan merupakan media informasi yang dibuat sedemikian rupa agar dapat menarik minat khalayak, memiliki karakteristik tertentu dan persuasif sehingga khalayak secara sukarela terdorong untuk melakukan suatu tindakan sesuai dengan yang diinginkan pengiklan (Jefkins, 1997:18). Iklan dapat dibuat dalam berbagai media periklanan. Media periklanan adalah saluran yang digunakan pemasang iklan dalam komunikasi massa. Pemilihan media merupakan bagaimana mencari cara yang efektif dan efisien dalam menyampaikan sejumlah pesan agar dapat sampai dengan jelas ke khalayak sasaran (Lamb at all, 2001:33).

Permasalahan yang dialami perguruan tinggi adalah persaingan yang semakin ketat dalam mendapatkan mahasiswa baru baik pada perguruan tinggi yang berstatus negeri atau swasta, yang dulunya hanya bersaing dengan sesama perguruan tinggi di daerah saja, namun sekarang pesaing yang harus ditaklukan adalah pesaing dari daerah lain bahkan internasional. Hal ini dapat disikapi dengan semakin mudahnya masyarakat menemukan informasiinformasi terkait perguruan tinggi diberbagai media promosi terutama media periklanan, dikarenakan khalayak yang dihadapi lebih selektif dalam menerima informasi.

Provinsi Bengkulu terdapat 5 (lima) Perguruan Tinggi Swasta yaitu Universitas Muhammadiyah Bengkulu (UMB), Universitas Hazairin (UNIHAZ), Sekolah Tinggi Ilmu Administrasi (STIA), Universitas Ratu Samban (UNRAS), dan
Universitas Dehasen (UNIVED), yang bersaing dalam merebut calon mahasiswa. Sebagai perguruan tinggi yang paling baru berdiri, Universitas Dehasen (UNIVED) Bengkulu gencar mengadakan kegiatan promosi yang dilakukan oleh pihak universitas melalui tim Panitia Penerimaan Mahasiswa Baru (PPMB) yang dibentuk setiap tahun ajaran baru oleh universitas. Penggunaan berbagai macam media periklanan menjadi pilihan utama dalam kegiatan promosi universitas dalam rangka menambah jumlah atau mempertahankan jumlah mahasiswa yaitu melalui iklan pada Media Lini Atas dan Media Lini Bawah. Berdasarkan kategorinya terdapat dua jenis media untuk menyampaikan pesan iklan yaitu Media Lini Atas (above the line media) adalah media yang tidak berinteraksi langsung dengan audience tetapi lebih menjelaskan sebuah konsep atau ide media dengan target audience yang luas seperti televisi, radio, surat kabar, dan media luar ruang. Sedangkan Media Lini Bawah (below the line media) adalah media yang kegiatannya memberikan kesempatan pada audience untuk merasakan, menyentuh atau berinteraksi bahkan langsung action, terdiri dari benda-benda pajangan, kalender, media video, event, cinderamata, dan lain-lain (Tjiptono,2008:73). Keberadaan berbagai media periklanan tersebut tentu saja semakin membuka ruang yang luas bagi UNIVED untuk dikenal dan menarik minat masyarakat luas.

$$
\text { Lukitaningsih }
$$

mengungkapkan kegiatan periklanan dengan menggunakan media lini atas memang memiliki keunggulan dalam mentransfer informasi ke masyarakat namun membutuhkan biaya yang tidak sedikit sehingga tidak bisa dilakukan setiap waktu, hanya dilakukan pada periode atau masa tertentu seperti pada masa penerimaaan mahasiswa baru saja. 
Media lini bawah dipilih karena tidak membutuhkan jasa pengiklan seperti pada media lini atas. Meskipun dianggap sebagai media minor atau pelengkap, namun beriklan pada media lini bawah juga memiliki peranan penting dalam suatu kampanye periklanan. Hal ini disebabkan karena media lini bawah dalam hal-hal tertentu bisa menjadi lebih efektif, tergantung bentuk iklan dan kampanye yang hendak dilakukan. Sifatnya yang non periodik merupakan kelebihan tersendiri karena dapat beriklan kapan saja dan dimana saja.

Penggunaan iklan yang beragam ternyata berimbas pada besarnya biaya iklan yang harus dikeluarkan oleh UNIVED. Mengingat biaya yang dikeluarkan untuk periklanan terbilang besar, maka bagi UNIVED diperlukan pengukuran efektifitas penggunaan iklan untuk perancangan dan pelaksanaan periklanan yang efektif kedepan sehingga biaya yang dikeluarkan tidak sia-sia. Belch dan Belch (2011:637) menyebutkan bahwa ada tiga alasan yang mendasari mengapa suatu iklan harus diukur efektifitasnya yaitu:

a. Avolding Costly Mistake

Dengan melakukan pengukuran terhadap efektifitas periklanan, dapat menghindari terjadinya kesalahan dalam biaya yang dikeluarkan dalam beriklan, sehingga biaya yang dikeluarkan tidak terbuang percuma untuk sesuatu yang tidak sesuai dengan tujuan. Ketika suatu program periklanan tidak memenuhi tujuan yang diharapkan, pengiklan dapat mengetahuinya dengan cepat dan dapat menghentikan pengeluaran uang yang terlalu banyak.

b. Evaluating Alternatif Strategies

Sebuah riset dapat membantu pengiklan menentukan strategi yang paling efektif dari lebih dari satu macam strategi periklanan yang dilakukan. c. Increasing The Efficiency of Advertising in General

Melalui riset efektifitas iklan, dapat membantu dalam menentukan pola komunikasi yang paling efektif dan efisien. Hal ini dikarenakan tidak semua orang memahami seluruhnya apa yang disampaikan karena terkadang sebuah iklan terlalu kreatif hingga nyaris kehilangan makna yang sesungguhnya.

Apabila pemilihan jenis media dilakukan secara tepat, penggunaan media dilakukan secara terus menerus, serta pemilihan waktu yang tepat terhadap kebutuhan informasi publik, maka keberadaannya dapat memberikan kontribusi secara maksimal dalam optimalisasi strategi periklanan berkaitan dengan pemilihan media agar dapat memaksimalkan biaya promosi. Perencanaan dan pemilihan media untuk periklanan memegang peran penting dalam proses penyampaian pesan iklan ke khalayak. Ketepatan dalam memilih media komunikasi tersebut akan menentukan keefektifan iklan. Setiap media periklanan tidak memberikan tingkat efektifitas dan efisiensi yang sama. Masing-masing media periklanan memiliki karakter yang mendukung dan karakter yang tidak mendukung terhadap tujuan publikasi. Pemilihan media yang kurang tepat, disamping tidak efektif, inefisien, juga dapat menimbulkan kerugian dalam hal materi dan waktu.

Adapun tujuan dari penelitian ini adalah untuk mengetahui bentuk perbedaan efektifitas iklan pada media lini atas dan media lini bawah yang digunakan Universitas Dehasen Bengkulusebagai masukan untuk strategi promosi selanjutnya. Agar penelitian lebih fokus dan tidak meluas, maka dalam penelitian ini penulis membatasi ruang lingkup penelitian adalah efektifitas pada tampilan iklan dalam media periklanan yang digunakan UNIVED terkait teks (tulisan), 
ilustrasi (gambar, foto), atau warna dengan menggunakan alat ukur pada dimensi EPIC Model yaitu Emphaty, Persuasion, Impact, dan Communication. Dimana media periklanan yang dimaksud dalam penelitian ini adalah media periklanan yang berisikan iklan tentang Universitas Dehasen Bengkulu pada beberapa media tertentu saja yang keberadaannya umum diketahui dan merupakan iklan yang sudah lama didistribusikan ke masyarakat luas antara lain:

a. Media Periklanan Lini Atas terdiri dari Media Cetak yaitu Suratkabar,Media Elektronik yaitu Televisi, dan Media Luar Ruang yaitu Baliho/Spanduk

b. Media Periklanan Lini Bawah terdiri dari Brosur/Leaflet (bersifat disebarkan), Poster (bersifat ditempel pada lokasi strategis), dan Reklame Berjalan (bersifat mobile).

\section{METODOLOGI PENELITIAN}

Jenis penelitian yang digunakan dalam penelitian ini adalah deskriptif kuantitatif dan menggunakan metode survey yaitu suatu upaya untuk mengumpulkan informasi dari responden dengan menggunakan kuisioner sebagai instrumen penelitian (Prasetyo, 2010:49). Agar peneliti tidak kehilangan informasi yang hanya dapat diperoleh dengan jalan bertanya langsung maka data akan didukung dengan hasil wawancara. Wawancara dapat berfungsi sebagai pelengkap metode utama yang digunakan dalam mengumpulkan data yaitu hasil penyebaran kuisoner (Lerbin, 2007:25).

Penelitian ini dilaksanakan pada mahasiswa semester 1(satu) tahun ajaran 2014/2015 yang mengetahui atau pernah melihat, mendengar dan membaca iklan UNIVED pada media lini atas dan media lini bawah dengan populasi sebanyak 1.051 orang dan dengan perhitungan rumus Slovin didapat 91 orang sampel yang ditentukan secara Purposive
Sampling dan Accidental Sampling dengan jumlah sampel ditentukan menggunakan probability sampling dengan teknik Proportionale Random Sampling.. Untuk mengetahui pendapat responden mengenai efektifitas media periklanan yang digunakan UNIVED tersebut, data dikumpulkan melalui beberapa pertanyaan dalam kuisioner dengan cara setiap mahasiswa menjawab enam kuisioner yang mewakili enam media periklanan. Tampilan iklan disertakan saat penyebaran kuisioner untuk mengingatkan responden.

Dalam penelitian ini variabel penelitian yang akan diteliti adalah efektifitas penggunaan media periklanan pada Universitas Dehasen Bengkulu yaitu iklan pada media lini atas meliputi Suratkabar, Televisi, dan Baliho/Spanduk $\left(\mathrm{X}_{1}\right)$ dan efektifitas iklan pada media lini bawah meliputi Brosur/Leaflet, Poster, dan Reklame Berjalan $\left(\mathrm{X}_{2}\right)$. Dan untuk mengukur efektifitas penggunaan media periklanan tersebut digunakan empat dimensi EPIC Model yaitu empathy, persuasion, impact, dan communication. EPIC Model menurut Durianto (2003:86) adalah salah satu alat ukur efektifitas iklan dengan pendekatan komunikasi. Salah satunya adalah komunikasi grafis yang terkait dengan tampilan iklan yaitu teks (tulisan), ilustrasi (gambar,foto), atau warna. Masing-masing dari dimensi akan memiliki sub dimensi yang juga akan diberikan indikator sebagai alat ukur.

Dimensi empati adalah keadaan mental seseorang yang mengidentifikasi diri pada perasaan atau pikiran yang sama dengan orang lain atau situasi yang dihadapi. Dalam penelitian ini, apakah konsumen menyukai suatu iklan dan menggambarkan bagaimana konsumen melihat hubungan antara suatu iklan dengan pribadi mereka. Sub dimensi yang digunakan respon afektif dan keterlibatan. Dimensi persuasif adalah perubahan kepercayaan, sikap dan keinginan 
berperilaku. Dalam penelitian ini menyangkut tingkat keterlibatan konsumen dalam penguatan karakter merk. Sub dimensi yang digunakan adalah Respon. Dimensi dampak adalah pengaruh yang mendatangkan akibat yang dapat membentuk watak, kepercayaan, atau perbuatan seseorang. Sub dimensi yang digunakan adalah Product Knowledgedan Keterlibatan. Dimensi komunikasi adalah bagaimana menafsirkan muatan/isi pesan dan jenis saluran yang digunakan untuk menyampaikan pesan iklan. Sub dimensi yang digunakan adalah kesadaran dan pemahaman.

Dalam penelitian ini skala pengukuran yang digunakan adalah skala Likert. Untuk mengevaluasi efektifitas iklan dengan analisis deskriptif EPIC Model digunakan perhitungan rata-rata berbobot atau skor rata-rata yaitu setiap jawaban responden dari pertanyaan yang diberikan diberikan bobot dan dianalisis dengan landasan teori Agenda Setting.Selanjutnya untuk menguji ada tidaknya perbedaan maka dilakukan dengan uji beda yaitu Paired Samples TTest. Analisa data dilakukan menggunakan alat bantu program SPPS (Statistic for Products and Services Solutions) versi 16.

\section{HASIL PENELITIAN DAN PEMBAHASAN}

Hasil analisis deskriptif untuk mengukur efektifitas iklan berdasarkan dimensi EPIC Model menunjukkan media periklanan yang digunakan UNIVED Bengkulu dalam menyampaikan pesan iklannya yaitu media lini atas dan media lini bawah berada pada skala penilaian yang efektif, terbukti dengan nilai skor rata-rata dari masing-masing media yang berada pada rentang penilaian 3,41-4,20. Hal ini menunjukkan bahwa media periklanan yang digunakan oleh UNIVED Bengkulu efektif dalam mempengaruhi khalayak sasaran untuk melanjutkan pendidikannya di UNIVED Bengkulu. Efektifitas media tersebut tidak terlepas dari kekuatan yang dimiliki oleh masingmasing media dalam mempengaruhi khalayak yang diukur melalui 4 dimensi EPIC Model yaitu Emphaty, Persusion, Impact, dan Communication yang didukung dengan hasil wawancara pada beberapa responden untuk lebih memperjelas kekuatan yang dimiliki masing-masing media.

Media periklanan lini atas yang digunakan UNIVED Bengkulu yaitu surat kabar, televisi, dan media luar ruang (baliho/spanduk) terbukti efektif dalam mempengaruhi khalayak yang dibuktikan dengan skor rata-rata sebesar 3,90 untuk media surat kabar, 3,84 untuk media televisi, dan 3,92 untuk media luar ruang (baliho/spanduk).

Media surat kabar secara emphaty mampu menyajikan pesan iklan yang mengacu kedekatan dengan khalayak sasaran secara emosional. UNIVED mampu menggunakan kelebihan visual pada media surat kabar yang membuat khalayak sasaran dapat berfikir lebih baik memahami iklan terkait dengan keberadaan atribut, konsekuensi dan nilai. Kekuatan ini tentu saja menguatkan karakter merk UNIVED di mata khalayak sasaran dan mampu menumbuhkan persepsi pada diri khalayak bahwa UNIVED identik dengan kebutuhan diri pribadi dan aktifitas pribadi. Dengan kata lain, secara efektif berdampak membangun pengetahuan akan kompetensi yang ditawarkan pada khalayak yang membaca. Sehingga juga mampu membangun kesadaran, pemahaman, dan tindakan khalayak sasaran dengan baik.

Hasil wawancara dengan beberapa orang responden menunjukkan teks iklan dalam surat kabar disajikan dengan baik sehingga mampu menumbuhkan persepsi pada khalayak sasaran tentang kompetensi 
yang ditawarkan UNIVED sehingga dapat memberikan ruang yang luas kepada masyarakat untuk memilih jurusan yang identik dengan kebutuhan pribadi dan aktifitas pribadi. Ilustrasi juga digunakan untuk membantu mengkomunikasikan pesan secara tegas yaitu dengan menampilkan kata-kata kunci seperti 'Mau Kuliah??? Ayo Bergabung Disini, 'Biaya Kuliah Bisa Diangsur' dan 'Gratis Biaya Pendidikan per Kecamatan'. Hal ini tentu saja mampu membangun kesadaran atau menggugah perhatian khalayak sehingga akhirnya melakukan tindakan untuk memilih UNIVED sebagai tempat melanjutkan pendidikan. Namun keberadaan posisi iklan dalam surat kabar yang berada bersamaan dengan iklan-iklan lain menyebabkan iklan tersebut tidak terlalu mencolok terlihat dalam halaman surat kabar.

Iklan UNIVED Bengkulu pada media televisi secara garis besar juga efektif mempengaruhi khalayak sasaran. Pesan yang disampaikan secara audio visual berupa gambar dan ilustrasi mampu menginformasikan dan menguatkan karakter merk UNIVED sebagai 'solusi cerdas untuk mewujudkan mimpi menjadi sarjana'. Kekuatan audio visual tersebut dapat membuat UNIVED terlihat menonjol dibandingkan universitas swasta lainnya dikarenakan pesan iklan yang disajikan mampu menumbuhkan persepsi pada diri kahalayak bahwa UNIVED identik dengan kebutuhan pribadi akan masa depan sehingga khalayak mempunyai keinginan yang kuat untuk melakukan tindakan melanjutkan pendidikan di UNIVED. Sebagian besar responden tertarik terhadap pesan yang menonjolkan sarana prasarana yang menunjang kenyamanan dalam proses belajar mengajar. Namun ada yang berpendapat alur cerita dalam iklan yang terkesan terlalu dramatisasi sehingga dapat mengaburkan makna pesan yang sesungguhnya.
Iklan UNIVED pada media luar ruang yaitu baliho/spanduk terlihat sangat menonjol karena secara emphaty iklan UNIVED pada baliho/spanduk mampu membangun respon khalayak secara emosional yaitu keterlibatan secara subjektif untuk memahami pesan iklan yang disajikan lewat baliho/spanduk dengan baik. Hal ini tentu saja dapat menguatkan karakter merk UNIVED di mata khalayak sasaran. Selain itu iklan UNIVED pada media baliho/spanduk juga mampu memanfaatkan kelebihan media luar ruang yang diletakkan di lokasi-lokasi strategis yang mampu mengkomunikasi pesan secara tegas memberi penjelasan terhadap keseluruhan pesan sehingga UNIVED terlihat menonjol dibandingkan universitas swasta lainnya dikarenakan dapat membantu menumbuhkan persepsi khalayak bahwa UNIVED identik dengan kebutuhan diri pribadi dan aktifitas kerja dalam kaitannya dengan pemilihan jurusan. Gambar dan warna yang menarik mampu membangun kesadaran atau menarik perhatian sebagian besar responden sehingga membangun pemahaman dan akhirnya melakukan tindakan untuk memilih UNIVED sebagai tempat melanjutkan pendidikan.

Media periklanan lini bawah yang digunakan UNIVED Bengkulu yaitu brosur/leaflet, poster, dan reklame berjalan juga terbukti efektif dalam mempengaruhi khalayak terbukti dengan skor rata-rata sebesar 3,75 untuk media brosur/leaflet, 3,75 untuk media poster dan 3,73 untuk media reklame berjalan.

Media brosur/leaflet terlihat lebih menonjol dibandingkan media lainnya dalam kategori media lini bawah karena iklan UNIVED pada media brosur/leaflet mampu menyajikan pesan iklan yang mengacu kedekatan khalayak sasaran secara emosional yaitu khalayak sasaran menyukai iklan. Secara emphaty, informasi yang disajikan lebih lengkap dengan desain yang menarik dan 
komunikatif. Dengan menyukai iklan tersebut, khalayak sasaran dapat berfikir dengan lebih baik dan memahami iklan terkait keberadaan atribut, konsekuensi dan nilai, dimana persepsi yang timbul bahwa UNIVED identik dengan kebutuhan diri pribadi dan aktifitas kerja. Sehingga secara garis besar iklan UNIVED melalui media brosur/leaflet mampu membangun kesadaran, pemahaman dan tindakan khalayak dalam membuat keputusan untuk melanjutkan pendidikan. Dengan kata lain brosur/leaflet secara efektif membangun pengetahuan dan kompetensi yang ditawarkan UNIVED pada khalayak pembaca sehingga menumbuhkan keinginan untuk bertindak mengambil kompetensi yang ditawarkan tersebut.

Hasil wawancara dengan beberapa responden menunjukkan teks pada brosur/leaflet menyampaikan pesan yang lengkap tentang kompetensi yang dimiliki UNIVED. Ilustrasi yang ditampilkan mampu menonjolkan keistimewaan dari produk dengan warna yang menarik perhatian. Tampilan-tampilan foto memiliki makna sehingga menguatkan karakter merk dan mempengaruhi responden.

Media poster memiliki kekuatan dimana UNIVED mampu memanfaatkan kelebihan poster tersebut untuk menyajikan iklan yang mampu menginformasikan dengan baik sehingga menguatkan karakter merk UNIVED di mata khalayak sasaran dikarenakan mampu membangun kesadaran, pemahaman dan tindakan khalayak sasaran dengan baik. Sebagian besar responden menyatakan perpaduan visual dari warna, gambar dan pesan mampu menarik perhatian, memperjelas ide dan mengilustrasikan fakta dengan kata-kata yang mudah diingat. Teks pada poster mampu merangsang minat karena menyampaikan pesan dengan singkat, padat, dan improfit. Hal ini yang menguatkan karakter merk UNIVED dimata responden. Namun ada sebagian tampilan foto dalam poster terkesan tidak memiliki makna dan tidak mendukung pesan. Hal ini tentu saja dapat mempengaruhi pemahaman responden tentang maksud dari pesan iklan yang disampaikan. Hal inilah salah satu yang menyebabkan poster berdampak belum dapat membantu responden secara maksimal untuk mengasosiakan iklan terkait dengan pengalaman yg menyenangkan kedepan saat melanjutkan pendidikan.

Keberadaan iklan UNIVED Bengkulu pada media reklame berjalan juga efektif mempengaruhi khalayak dikarenakan cakupan objek yang luas membuat pesan yang disampaikan dapat dibaca dimana saja. Namun efektifitas tersebut tidak terlalu menonjol seperti pada media brosur/leaflet dan poster. Hasil wawancara pada beberapa responden menunjukkan warna yang mencolok dan ilustrasi yang diberikan mampu membantu mengingatkan responden akan keberadaan UNIVED sebagai lembaga pendidikan. Namun teks yang disampaikan dalam iklan sangat terbatas karena ruang iklan yang sempit. Khusus pada penelitian ini, tampilan iklan yang dimiliki UNIVED tidak terlalu menekankan pada pesan untuk mengajak responden menjadi bagian dari UNIVED. Dalam kata lain ada pesan lain yang lebih menonjol.

Berdasarkan penjelasan di atas maka dapat diketahui bahwa setiap media memiliki kekuatan dan kelemahan dalam mempengaruhi khalayak sasaran. Iklan UNIVED pada media lini atas memang memiliki rata-rata nilai efektifitas yang lebih dibandingkan iklan UNIVED pada media lini bawah. Namun keberadaan iklan media lini bawah dalam situasi tertentu sangat berperan penting dalam upaya promosi dibandingkan media lini atas. 
Efektifitas media periklanan tidak terlepas dari faktor lain yang dapat memberikan kontribusi seperti penggunaan media tersebut yang bersifat luas dan dapat digunakan dalam setiap kegiatan promosi seperti dalam kegiatan yang dilakukan dosen dan mahasiswa. Seperti media brosur/leaflet dapat digunakan dalam kegiatan lapangan dosen yaitu kunjungan ke sekolah-sekolah, road show atau kunjungan ke daerah-daerah, dan kegiatan pengabdian masyarakat. Dalam kegiatan mahasiswa media tersebut juga dapat berperan seperti dapat disertakan dalam pelaksanaan event atau kegiatan mahasiswa, kegiatan $\mathrm{KKN}$ atau promosi yang dilakukan dari mulut ke mulut oleh mahasiswa saat kembali ke daerah masing-masing.

\section{PENUTUP}

Berdasarkan hasil penelitian dan pembahasan maka dapat disimpulkan bahwa bentuk perbedaan efektifitas Iklan UNIVED Bengkulu yang disajikan pada media lini atas dan media lini bawah dalam mempengaruhi khalayak sasaran dapat dilihat dari perbedaan kekuatan yang dimiliki masing-masing media. Iklan pada media lini atas, secara emphaty mampu memanfaatkan kelebihan yang dimiliki seperti kelebihan visual pada media surat kabar, audio visual pada media televisi, dan nilai strategis yang dimiliki media spanduk/baliho. Sehingga secara persuasion mampu menguatkan karakter merk yaitu dapat menumbuhkan persepsi bahwa UNIVED identik dengan kebutuhan pribadi karena mampu membangun kesadaran, pemahaman, dan tindakan khalayak dengan baik. Sedangkan Iklan pada media lini bawah juga terbukti efektif mempengaruhi khalayak sasaran terutama pada media brosur/leaflet yang memiliki kelebihan visual dan ruang yang luas untuk menyampaikan pesan iklan. Media poster juga memiliki kekuatan visual yang sama namun belum dapat membantu secara maksimal dalam mengasosiasikan iklan dengan pengalaman yang menyenangkan yaitu cita-cita masa depan karena peletakan gambar yang tidak mendukung dapat mempengaruhi pemahaman khalayak. Media reklame berjalan juga memiliki nilai efektifitas yang baik dikarenakan sifatnya yang mobile mampu mengingatkan khalayak akan merk. Namun ruang iklan yang sempit kurang menyampaikan pesan iklan.

Iklan UNIVED Bengkulu pada media lini atas dan media lini bawah memang terbukti efektif berdasarkan dimensi EPIC Model. Namun masih terdapat beberapa kelemahan yang harus diperhatikan mengingat sekarang ini persaingan dalam aktifitas periklanan sangatlah sengit. Seperti tampilan iklan yang terkesan dramatisasi atau memasukkan unsur lain yang tidak mendukung pesan sehingga tidak mampu meyakinkan khalayak. Hal ini perlu sangat mendapat perhatian karena ketika produk/jasa tidak diyakini secara penuh maka akan muncul keengganan dalam diri khalayak untuk menggunakan produk/jasa yang ditawarkan tersebut.

Dalam upaya mengurangi biaya iklan agar efektif dan efisien, maka penggunaan media periklanan perlu direncanakan secara optimal dengan melihat kekuatan yang dimiliki oleh masing-masing media. Iklan UNIVED pada media lini atas memang memiliki rata-rata nilai efektifitas yang lebih dibandingkan iklan UNIVED pada media lini bawah. Namun keberadaan iklan media lini bawah dalam situasi tertentu sangat berperan penting dalam upaya promosi dibandingkan media lini atas. Untuk itu agar hasil yang didapat dalam upaya mendapatkan mahasiswa baru berjalan maksimal maka perlu adanya perencaanan yang tepat dalam penggunaan media kedepan dengan mengurangi penggunaan media yang 
lemah dan memaksimalkan media yang memiliki kekuatan. Salah satu contohnya adalah biaya iklan televisi dikurangi dan dialihkan ke kegiatan promosi lain seperti event atau roadshow yang dapat mendukung penyebaran media seperti brosur/leaflet.

\section{DAFTAR PUSTAKA}

Belch, George dan Michael Belch. 2011. Introduction Advertising and Promotion: An Integrated Marketing Communication Perspektive: Second Edition. United States of Amerika, Irwin

Indrajit, R. Eko dan Djokopranoto. 2006. Manajemen Perguruan Tinggi Modern. Yogyakarta, Andi Offset

Jefkins, Frank. 1997. Periklanan. Jakarta, Erlangga

Lamb, Charles W, Hair, Joseph H dan Mc Daniel Carl. 2001. Pemasaran. Buku Satu. Edisi Pertama. Jakarta, Salemba Empat

Lerbin. 2007. Metode Penelitian. Bandung, Remaja Rosdakarya Lukitaningsih, Ambar. 2013. Iklan Yang Efektif Sebagai Strategi Komunikasi Pemasaran. Jurnal Ekonomi dan Kewirausahaan Volume 13 Nomor 2 Halaman 116-129
Prasetyo, Bambang. 2010. Metode Penelitian Kuantitatif. Jakarta, PT. Raja Grafindo Persada

Prisgunanto, Ilham. 2006. Komunikasi Pemasaran : Strategi dan Taktik. Bogor, Ghalia Indonesia

Singarimbun, Masridan Effendi, Sofian. 1995. MetodePenelitian Survey. Jakarta, PT. Pustaka LP3ES

Sriyanto. 2006. Pemanfaatan Media Periklanan Dalam Upaya Menarik Minat Calon Mahasiswa Baru Pada APIKES Citra Medika Surakarta. Universitas Sebelas Maret, Laporan Penelitian

Sugiyono. 2011. Statistik Untuk Penelitian. Bandung, Alfabeta

Tjiptono, Fandi. 2008. Strategi Pemasaran. Yogyakarta, Penerbit Andi

Uyanto, Stanislaus S. 2009. Pedoman Analisa Data dengan SPSS Edisi 3. Yogyakarta, Graha Ilmu

Wijaya, Heniska. 2009. Analisis Pemanfaatan Media Lini Atas dan Media Lini bawah Terhadap Minat Beli Konsumen Pada Produk Hexos. Universitas Bina Nusantara, Tesis 